\title{
Does Diaspora Remittances Enhance Productive Asset Purchase in Host country? Evidence from Nigeria
}

Anochiwa Lasbrey, Michael Oguwuike Enyoghasim*, Agbanike Tobechi, Njoku Sunday, Emenogu Augustine C, Agu Chibuzo Glory

${ }^{1}$ Department of Economics and Development Studies, Alex Ekwueme Federal University Ndufu-Alike, Nigeria

DOI: $10.36348 /$ sjef.2020.v04i12.011 | Received: 02.11 .2020 | Accepted: 12.11 .2020 | Published: 30.12 .2020

*Corresponding author: Michael Oguwuike Enyoghasim

\section{Abstract}

It is no longer a debate that international remittance has a positive influence on economic growth as it goes into individuals to meet family needs, but what has not been settled empirically (at least in the case of Nigeria) is the end-use allocation of this resources. This study assesses the expenditure pattern of international remittances on productive assets purchase using a micro cross-sectional data obtained from 2009 World Bank's Migration and Remittances Survey in Nigeria. The model estimated was based on a new approach, using the bivariate probit regression equation which saw remittances and productive assets as endogenous variables determined by some observed variables. The main result is the insignificant positive effect of migrant remittances on propensity to acquire productive assets among Nigeria's households.

Keywords: Remittances, Diaspora, Productive Assets, Migration, Economic growth.

JEL Classification: D13, O15.

Copyright (C) 2020 The Author(s): This is an open-access article distributed under the terms of the Creative Commons Attribution 4.0 International License (CC BY-NC 4.0) which permits unrestricted use, distribution, and reproduction in any medium for non-commercial use provided the original author and source are credited.

\section{INTRODUCTION}

Remittances of international migrants to developing countries are attracting great attention in the contemporary times because of the quantum of transaction which is estimated to have risen considerably over the years. Recent estimates show an increase from US $\$ 432$ billion in 2015 to US\$516 billion in 2016 [1, 2]. Remittances to Nigeria rose every year over the last decade, from $\$ 16.93$ billion in 2006 to $\$ 20.83$ billion in 2014 , making Nigeria the sixth largest recipient of remittances in the world. It is no longer a debate that remittance goes into individuals to meet family needs, but what has not been settled empirically (at least in Nigeria) is the specific thing the money is used for. Some studies argue that remittances are mainly spent on immediate consumption goods such as food and utilities [3-5] while an alternative view in the literature asserts that households consider remittances to be a form of transitory income which will be spent more at the margin on human and physical capital investments than on consumption goods [6-8].

A lot of research has gone into the impact of remittances on the growth of an economy and as an agent for poverty reduction. However, the issue of productive asserts acquisition seems a recent phenomenon, especially in Nigeria. The term "remittances" basically refers to the transfers, in cash or in kind, from a migrant to household residents in the country of origin. Remittances are referred to as unrequited transfer sent by migrant workers back to relatives in their countries of origin [9]. Remittances are person-to person flows, well targeted to the needs of the recipients, and these gifts and or money, do not typically suffer from unnecessary international monetary regulations often associated with official aid flows.

Fundamentally, remittances are personal flows from migrants to their families and friends [10, 11]. Ratha [12] portrays remittances as the most tangible and least controversial link between migration and development because of its stability and counter- cyclicality over time compared to other private flows.

That remittances are agents of growth is incontrovertible. As Bang et al., [13] observed there is more agreement than disagreement with regard to the impact of remittances on growth and poverty; most of the evidence in the literature suggests that remittances enhance growth and reduce poverty. Studies such as 
Catrinescu et al., [14] and Feeny et al., [15] support the poverty reduction hypothesis by emphasizing that remittances stimulate financial development. Meanwhile, Giuliano and Ruiz Arranz [16]; Mundaca [17]; Aggarwal et al., [18]; Chowdhury [19] focused on human capital formation and found that remittances enhance development through increasing educational expenditure at the household level. But, that remittances are used for consumption alone or purchase of productive assets is omnibus and the boundaries of that argument is fluid.

This paper seeks to contribute to the longstanding debates in the literature concerning the use of remittances by households. Do Nigerian households utilize remittances in a productive manner through acquiring productive assets or purely for consumption? What is the composition of remittances on productive assets acquisition among households in Nigeria; and do remittances alleviate receiving household's financial constraint? These are some of the questions we will attempt to answer. The objectives of this study are;

- To examine whether remittances impact significantly on productive assets acquisition in Nigeria.

- To examine the type of remittances that contributes to the acquisition of productive assets in Nigeria.

- Do remittances significantly alleviate household financial constraint?

\section{Literature Review and Theoretical Framework}

Theories associated with the impact of remittances on development are hinged on three underpinning points: Again, one of the arguments that favoured this research is the classification of remittance end-use into three [6]. Much of the empirical works we have cited early seems to suggest that in all, remittances are beneficial to the host country. Developmental Optimistic School which sprang out of the neoclassical school of thought on migration hypothesis holds the view that remittances are beneficial to development of the host country. The second is the Developmental Pessimistic School that is largely influenced by the structuralism dependency school. They anchor their view on the negative effects of remittances. The third is a combined position of the two earlier ones inspired by the Remittances Development Pluralists. [20-23]. We shall attempt to highlight these three positions briefly.

\section{The Developmental Optimistic View}

The Developmental Optimistic view became prominent in 1950s and 1960s. it assumed that those who move to the western world in what we call NorthSouth migration transfer money to their loved ones at home. And this "North-South" transfers of investment capital also come with it enhancement of labour of the exporting countries due to their exposure to "liberal, rational and democratic ideas, modern knowledge and education" [21]. The general assumption the followers of this theory portend is that flows of remittances as well as experience, skills and knowledge that migrants acquire abroad will enhance development in the recipient countries [21, 24, 22]. In the Neoclassical model of balanced growth, migration is a process contributing to optimal allocation of production factors, which benefit all equally, both the countries of origin and the recipients [22]. In an unconstrained market environment, free labour mobility will lead to scarcity of labour, and hence the marginal productivity of labour will increase and lead to higher wages in the migrant sending countries $[22,25,26]$.

\section{The Developmental Pessimistic View}

In the late 1960s a new viewpoint regarding remittances, migration and development emerged; referred to as the pessimistic view. The theory arose from a shift in social science towards more structural views [22]. This theory suggests that the net effect of migration and remittances does not foster sustainable development [21]. The brain drain is one of the aspects considered, where emigration of the educated leads to a loss that is not offset by the benefits associated with remittances [27-33]. The developing countries are drained of their human capital resources when educated inhabitants emigrate.

They argue that the recipients are not as enlightened to make investment decisions therefore, the recipient might not be as skilled as domestic financial intermediaries; therefore the investment is less likely to be successful [34-36]. Money would rather be spent on consumption or non-productive investments such as real estate and rarely in productive enterprises [21]. If the money received is spent mainly on consumption, rather than investment, this could encourage more rapid inflation in the remittance receiving developing countries [37, 36, 38, 39]. Diaspora income is a largess and could lead to crowding out effect. Increased wealth, generated by remittances, could challenge the receiver'

\section{The Developmental Pluralistic View}

The third variant often referred to as Developmental Pluralistic View is not so much a theory but rather an anti-thesis of both the positive and pessimistic view that arose in the 1980s and 1990s. The pluralistic view aims to link causes and consequences of migration more explicitly, in which both positive and negative effects on development are possible [22]. They argue that because of the complexity of remittances and development, there is a need of more dynamic understanding of the relationship between them. Neither the optimistic nor the pessimistic view provides this [21]. According to this theory the fundamental question is not whether migration has a strictly negative or positive impact on development, the effects of remittances are thus context-dependent [22, 23].

Skepticism about the use of migrant remittances for productive investments has become the common thread of the migration and development 
debate. In this research, we stand by the proposition that a significant proportion of remittances are spent on savings and investment while a small fraction is spent on consumption. Notwithstanding, a cursory look at empirical findings of the pessimistic view of remittance expenditure among household will be worthwhile.

Empirical findings have made it no longer a debate that migration can generate output growth either by increasing consumption or increasing investment through multipliers [40, 41, 9]. Beginning with the pessimistic view, World Bank [1], investigated the impact of remittances on the expenditure pattern of rural households with data from Ethiopia Rural Household Survey (ERHS), using the Two- part model or (Hurdle model) within Engel's Curve framework. Their findings show absence of any strong link between remittance income and investment expenditure on the first model, and in the second part it found a positive and robust link with consumption expenditure.

Amel S. Omer et al., [42] explored the effects on health of both household asset inequality and political armed conflict in Sudan; with data drawn from 2010 Sudan Household survey to evaluate the role of household distribution and conflict status. They should variables such life expectancy, infant mortality, heightfor-age (stunting), adequacy of food consumption, teenage birth rates and vaccination coverage for young children. Their findings show that states with unequal distribution of wealth suffer more in conflict and significantly worse-off in health.

Yameogo [43], for Burkina Faso analyzed the impact of remittance on household expenditure with data from the 2010 Cross-Sectional Survey using a Latent Class Model (LCM). Its result shows that remittance is significantly and positively related with expenditure on food and other utilities. It went further to investigate remittance inflow and household expenditure pattern in Kenya, using a Fixed Effect (FE) model on a panel of 295 households. In their findings, remittance is significant and positively related to consumption of food and public utilities.

A recent survey by Urama et al., [5] who used panel data from Indonesian Family Life Survey conducted survey between 2000-2007 also found that household spent more of their margin on food compared to what they would have spent without the receipt of remittances. Urama et al., [5] also took a study of Tajikistan, using a Propensity Score matching Method, and found that neither internal nor external remittances have a positive effect on investment expenditure. These studies lend support to the pessimistic view that households spend more of their remittances on food and barely on productive investment.

Conversely, authors of optimistic view say remittances could be more investment prone than consumption; beginning with Quartey [44], who used data from Malawi Integrated Household Survey November 1997-October 1998 and undertook responses from 2,046 households to investigate how remittances are spent in Malawi. They used the Ordinary Least Squares (OLS) method to estimate income elasticity and the Inverse Mill's Ratio (IMR) to control for selection bias. Their findings show that households in Malawi choose to allocate income from remittance differently from other forms of income.

Further, Simon et al., [45], used a panel data obtained from 115 developing countries in 2007 to investigate how households spend their remittances. They found that households allocate less on food and more of their income on investment good like housing, education as well as other entrepreneurial activities. In another related research during the same period Soraya [46], used a cross-country analysis to investigate how households spend their remittances and their findings indicates that households used more of their remittance income on savings and investment than other consumption.

In another empirical work Udah [6], used two approaches to examine the impact of remittances on expenditure pattern of house-holds in Kyrgyz Republic. The researchers employed the use of Seemingly Unrelated Regression (SUR) and Propensity Score Matching (PSM) model. Result from their findings using the two methods show that remittances increase the share of expenditure on durable goods such as human capital investment and construction.

Jena $F$ [47] used instrumental variable and recursive probability model to investigate the migrant remittances and physical investment purchases in Kenya and found that remittances have a positive effect on household purchases of physical investment. In another related work, Agwu et al., [9] employing quantile regression method using household expenditure as a proxy for household income to examine the impact of remittances on income inequality where they posit that remittances are used in productive ways by households which invariably improve the household welfare. That remittance enhance household expenditure at all quantiles of expenditure distribution but the impact is not uniformly distributed along income levels. The standard quantile regression suggests that the impact of remittances graduates from the lowest to the topmost quantile of income distribution.

In a recent work by Denis et al., [48], the study assesses the expenditure patterns of international remittances; comparing between remittance recipient households and non-recipient households in Nigeria. Household data was sourced from Anambra and Enugu states of Nigeria in November 2011 for the study. Using the working lesser model, this study finds that 
remittance into Nigeria has a stabilizing effect on its expenditure, as the marginal difference between remittance recipient households and non-recipient households is not significant for most of the expenditure types. However, remittance expenditures on shares/stock market investments are relatively lower than in non-recipient households. Meanwhile remittance expenditures on buildings, funerals and family subsistence are relatively higher than non-recipient household's expenditure.

In summary, it is obvious that the debate on household expenditure pattern skewed towards food consumption, while others are heavily skewed towards investment and asset purchase. It will be too bogus to use panel results from other countries to determine the outcome of another country in this regard. This is because the dynamics of end-use differs from country to country depending on its peculiarities. Denis et al., [48], gives us a lead to follow in our analysis though we have deliberately chosen to use different model to analyze the impact. Nevertheless, there are relatively few works of this kind in Nigeria. This therefore stands out as our point of departure in this paper.

\section{DATA AND METHODS}

In this research, a single-round cross-sectional survey with information on household characteristics, household assets and expenditures, households with migrants, returning migrants and remittances received was obtained from the 2009 World Bank's Migration and Remittances Survey in Nigeria. The survey was commissioned in September 2009. The survey was nationally representative and it followed a stratified random sampling with 18 out of the 36 states and the Federal Capital in Nigeria selected, in which 2251 households were successfully interviewed.

In analyzing and presenting data, the research work is conducted using an econometric methodology of probit regression model. A probit regression model is best suited for capturing binary indicator dependent variables. The data obtained is fitted by the recursive probit and instrumental variable analysis. This technique is used because it facilitates model specification, parameter estimation and aids in formulation of good policies. However, recursive bivariate probit was used to cater for endogeneity problem.

The model specification of this study is therefore as follows:

The functional form of the model is specified as;

$\mathrm{P}(\mathrm{Y}=1 / \mathrm{X})=\mathrm{G}(\mathrm{X} \beta) \equiv \mathrm{P}(\mathrm{X})$.

' $\mathrm{X}$ ' is the vector that captures the covariates used in the regression.

' $G$ ' is the normal cumulative function (cdf).

The specific form of $G$ can be derived from an underlying latent variable model given as;

$$
\mathrm{y}^{*}=\mathrm{X} \beta+\varepsilon
$$

Where;

$\mathrm{y}=1\left[\mathrm{y}^{*}>0\right]$.

The Evaluation is based on Econometric Criteria

The recursive bivariate probit model is presented below:

$\operatorname{prod}_{\mathrm{it}}=\alpha_{1}$ remit $_{\mathrm{it}}+\varkappa_{1} \beta_{1 \mathrm{it}}+\mu_{1 \mathrm{it}}$

Remit $_{\text {it }}=x_{2} \beta_{2 \mathrm{it}}+\mu_{2 \mathrm{it}}$

"prod and remit" are latent variables reflecting household's propensity to acquire productive assets and remittances.

' $x_{1}$ ' includes covariance aiding household's incentive to acquire productive assets.

While $x_{2}^{\prime}$ represents covariance aiding remittance.

$\operatorname{prod}_{\text {it }}=\left\{\begin{array}{l}1 \text { if prodit }>0 \\ 0 \text { if prodit } \mathrm{y} \leq 0\end{array}\right.$

Remit $_{\text {it }}=\left\{\begin{array}{c}1 \text { ifremitit }>0 \\ 0 \text { ifremitit } \leq 0\end{array}\right.$

Where;

Prod $_{\text {it }}$ And Remit represent whether the household received remittances and the actual decision of whether to spend on productive assets as included in equation (2).

The survey of 2251 households show that total of 724 households receives remittance within the last 1 year making a total of $32.16 \%$ from the total household survey, while only 421 households have acquired productive assets making $18.70 \%$ of the total household survey(see Table-1 and Table-2).

\section{RESULTS AND INTERPRETATION}

Table-1: Households and receipts of remittance

\begin{tabular}{|l|rll|}
\hline Remittance & Freq. & Percent & cum. \\
\hline 0 & 1,527 & 67.84 & 67.84 \\
& 724 & 32.16 & 100.00 \\
\hline Total & 2,251 & 100.00 & \\
\hline
\end{tabular}

Table-2: Households and acquisition of productive assets

\begin{tabular}{|l|ccl|}
\hline Asset & Freq. & Percent & Cum. \\
\hline 0 & 1,830 & 81.30 & 81.30 \\
1 & 421 & 18.70 & 100.00 \\
\hline Total & 2,251 & 100.00 & \\
asset & Freq. & Percent & Cum. \\
\hline 0 & 1,830 & 81.30 & 81.30 \\
1 & 421 & 18.70 & 100.00 \\
\hline Total & 2,251 & 100.00 & \\
\hline
\end{tabular}

Source: Researcher's computation; stata 14

From the Table-1 above, a total of 1527 Households did not receive remittance, while from Table-2 a total of 1830 households did not acquire productive assets. 
Table-3: Households that receive remittance without purchase of productive asset

\begin{tabular}{|l|lc|l|}
\hline Remittance & Asset & 1 & Total \\
\hline 0 & 0 & 225 & 1,527 \\
\hline 0 & 1,272 & 166 & 724 \\
\hline 1 & 558 & 421 & 2,251 \\
\hline Total & 1830 & \multicolumn{2}{|l|}{} \\
\hline
\end{tabular}

Source: Researcher's computation; stata 14
From Table-3 above, households that received remittance and not acquiring productive assets is estimated to be 558 out of 724 households, while a total of 255 households acquired productive assets but did not receive remittance. We proceed to conduct Analysis Of Variance (ANOVA) which is used to test and define the significance of the mean of the two groups.

Table-4: ANOVA Result

Analysis of Variance

\begin{tabular}{|c|c|c|c|c|c|}
\hline Source & SS & Df & MS & $\mathbf{F}$ & Prob $>$ F \\
\hline Between groups within groups & 1.90548777340 .355729 & 2249 & $1,90548777.151336474$ & 12.59 & 0.0004 \\
\hline Total & 342.261217 & 2250 & .152116097 & & \\
\hline
\end{tabular}

The result on the ANOVA table 4 above, shows that the variables are significantly different. The prob> F being below 0.05 , and the F-stat being above 1.96 using a $10 \%$ level of significance, we reject the null hypothesis of no difference. This implies that we have accepted the alternative hypothesis of statistically significant difference between the remittances and productive assets data collected by the survey, making the data suitable for further analysis.

\section{Estimation of Household characteristics}

The estimation takes into account household characteristics such as total household expenditure, household size, and other characteristics of the household head such as age, gender, marital status, employment status, and education. The survey does not provide information on household wealth, however, the study controlled for household wealth with proxies such as household ownership of computer, ownership of car truck and ownership household fridge, also the regressions also take into account urban and regional dummies respectively as shown in Table-5.

Table 5: Estimation of Household characteristics

Marginal effects after biprobit

$\mathrm{y}=\operatorname{pr}($ asset -1 , remittance $=1)($ predict $)$ $=0.05853467$

\begin{tabular}{|l|l|l|l|l|ll|l|}
\hline Variable & $\mathrm{dy} / \mathrm{dx}$ & $\mathrm{std} . \mathrm{Err}$ & $\mathrm{z}$ & $\mathrm{p}>[\mathrm{z}]$ & {$[95 \%$ C. I $]$} & $\mathrm{X}$ \\
\hline intoth $\sim \mathrm{p}$ & 0.0398555 & .00426 & 9.36 & 0.000 & .031513 & .048198 & 11.5615 \\
\hline hheadsex* & -.0204167 & .01235 & -1.65 & 0.098 & -.044616 & .003783 & .859128 \\
\hline hhloca $\sim \mathrm{n}^{*}$ & -.0323123 & .00787 & -4.10 & 0.000 & -.047745 & -.016879 & .507427 \\
\hline hhfridge* & -.0114721 & .00869 & -1.32 & 0.187 & -.028498 & .005554 & .49976 \\
\hline hhcar* & -.0190486 & .00943 & -0.77 & 0.442 & -.025735 & .011233 & .240537 \\
\hline hhcomp $\sim \mathrm{r}^{*}$ & -0.190486 & .00934 & -2.04 & 0.041 & -.037356 & -.000741 & .163872 \\
\hline educat $\sim \mathrm{s}$ & -.6212194 & .60571 & -3.72 & 0.000 & -.032406 & -.010032 & 1.77432 \\
\hline hhfule $\sim \mathrm{y}^{*}$ & -.0263203 & .01212 & -2.17 & 0.030 & -.050077 & -.002564 & .837566 \\
\hline hhhead $\sim \mathrm{s}^{*}$ & .0923274 & .01112 & 8.30 & 0.000 & .070536 & .114119 & .355055 \\
\hline hhhead $\sim \mathrm{e}$ & .0002263 & .0003 & 0.76 & 0.446 & -.000355 & .000808 & 49.5644 \\
\hline Hhsize & -.0005856 & .00117 & -0.50 & 0.618 & -.002884 & .001713 & 5.78965 \\
\hline
\end{tabular}

(*)dy/dx is for discrete change of dummy variable 0 to 1

Source: researcher's computation; stata 14

The result in Table-5, show that all things being equal, household expenditure (Intothexp), household location (hhlocation), education status (education status), household full emploment (hhfulemployment), and household marital status (hhheadmarital status), are all statistically significant as a propensity to acquire productive assets and receive remittance, while, hheadage, hheadsize, hhcar, hhfridge, and hhsex are not statistically significant determinants of productive assets acquisition and remittance. Hence, the significant variables will be used for further analysis. The simple probit regression is used to run productive assets on remittances received by households. The variable $\mathrm{x}_{1} \beta_{1 \mathrm{i}}$ represents other latent variable aiding productive assets. See details in appendix A (Bivariate probitregression)

\section{Objective 1}

To examine whether remittances impact significantly on productive assets acquisition in Nigeria. The probit regression equation in 2 is used. That is $\operatorname{prod}_{i t}=\alpha_{1}$ remit $_{\text {it }}+x_{1} \beta_{1 \text { it }}+\mu_{1 \text { it }}$

The variable $\mathrm{x}_{1} \beta_{1 \mathrm{i}}$ represents other latent variable aiding productive assets. 
Table-6: Estimates of the probit model

Marginal effects after biprobit

$\mathrm{y}=\operatorname{pr}($ asset $)$ (predict)

$=0.17251402$

\begin{tabular}{|c|c|c|c|c|c|c|c|}
\hline Variable & $\mathrm{dy} / \mathrm{dx}$ & std. Err & Z & $p>[z]$ & \multicolumn{2}{|l|}{$[95 \%$} & $\mathrm{X}$ \\
\hline remitt e* $^{*}$ & 0.238869 & 0.02973 & 1.15 & 0.249 & -.016139 & .064513 & .334603 \\
\hline hhhead $\sim \mathrm{s}^{*}$ & .0069443 & .0199 & 0.35 & 0.727 & -.032063 & .045 & .356497 \\
\hline hhful &,- 0129488 & .02321 & .56 & 0.577 & -.658437 & .0325 & 836744 \\
\hline educat $\sim \mathrm{s}$ & -.0499728 & .01269 & -3.94 & 0.000 & -.074838 & -.025108 & 1.7763 \\
\hline hhcomp r* & -.0716628 & .02118 & -3.38 & 0.001 & -.113177 & -.030148 & .164683 \\
\hline hhloca $\sim \mathrm{n}^{*}$ & -.0926117 & .01789 & -5.18 & 0.000 & -.127684 & -.05754 & .509757 \\
\hline Intoth p & .0683051 & .00793 & 8.61 & 0.000 & .05276 & .083851 & 11.5684 \\
\hline
\end{tabular}

$(*) \mathrm{dy} / \mathrm{dx}$ is for discrete change of dummy variable 0 to 1

Source: researcher's computation; stata 14

The result from the Table- 6 above, show that remittances do not impact significantly on productive assets acquisition. From the result, it shows all other variables held constant, households that receive remittances have an increased probability of acquiring productive assets by 0.0238869 compared to nonremittances receiving households. Also the results obtained show a positive and insignificant impact of remittances and acquisition of productive assets due to p-value $>0.05$

The significance of remittance do not in this paper conform to empirical conclusion on our a priori expectation. This could be explained that remittances received by households are being utilized by households for consumption purposes. Thus, remittances received are channeled into immediate consumption. Prior to the research, it was expected that remittances play significant impact on productive assets accumulation; as households receive remittances, they tend to acquire productive assets. From the result we reject the alternative hypothesis.

\section{Objective 2:}

To examine the type of remittances that contributes to the acquisition of productive assets in Nigeria.

To achieve this objective, we considered the research question: "what type of remittances impacted on productive assets acquisition in Nigeria?" In order to test this hypothesis, we would use equation 2 also, $\left(\operatorname{prod}_{\mathrm{it}}=\alpha_{1}\right.$ remit $\left._{\mathrm{it}}+x_{1} \beta_{1 \mathrm{it}}+\mu_{1 \mathrm{it}}\right)$ and type remittances (local and international) and the significant variables used in achieving the broad objectives. Following dummy specification the regression was made in the natural log of odds and presented below. The result as interpreted is titled Table 7 indicating the marginal effect estimates.

Table-7: Marginal effects after probit

Marginal effects after biprobit

$\mathrm{y}=\operatorname{pr}($ asset$)$ (predict)

$=0.17166872$

\begin{tabular}{|l|l|l|l|l|ll|l|}
\hline Variable & $\mathrm{dy} / \mathrm{dx}$ & $\mathrm{std} . \mathrm{Err}$ & $\mathrm{z}$ & $\mathrm{p}>[\mathrm{z}]$ & {$\left[\begin{array}{l}95 \% \\
\text { C.I }\end{array}\right.$} & $\mathrm{X}$ \\
\hline Int_re $\mathrm{t}^{*}$ & -.022517 & .02491 & -0.90 & 0.366 & -.071344 & .02631 & .149453 \\
\hline Loc_re $\sim \mathrm{t}^{*}$ & .0591433 & 0.2593 & 2.28 & 0.23 & .008318 & .109968 & .18515 \\
\hline Intoth $\sim \mathrm{p}$ & .070496 & .00796 & 8.85 & 0.000 & .054885 & .086107 & 11.5684 \\
\hline hhloca $\sim \mathrm{n}^{*}$ & -.0913718 & .01788 & -5.11 & 0.000 & -.126424 & -.05632 & .509757 \\
\hline hh.comp $\sim \mathrm{r}^{*}$ & -0.0703229 & .02123 & -3.31 & 0.001 & -.111941 & -.028705 & .164683 \\
\hline educat $\sim \mathrm{s}$ & -.0483147 & .01269 & -3.81 & 0.000 & -.073184 & -.023445 & 1.7763 \\
\hline hhfule $\sim \mathrm{y}^{*}$ & -.0132302 & 0.232 & -0.57 & 0.568 & -.058697 & .032236 & .836744 \\
\hline hhhead $\sim \mathrm{s}^{*}$ & .0061997 & .01987 & 0.31 & 0.755 & -.032739 & .045138 & .356497 \\
\hline
\end{tabular}

$(*) \mathrm{dy} / \mathrm{dx}$ is for discrete change of dummy variable 0 to 1

Source: researcher's computation; stata 14

Table-7 result above shows that all other variables held constant, local remittances (loc_remit) significantly impact on productive assets. From the result, it shows that households that receive local remittances have an increased probability of acquiring productive assets by 0.0591433 compared to nonremittance receiving households. While international remittance (int_remit) has a negative and insignificant impact on the propensity to acquire productive assets thus reduce households' probability of acquiring productive assets by 0.022517 compare to nonremittances receiving households. Local remittances have a positive and significant impact on the propensity to acquire productive asset due to $\mathrm{p}$-value $<0.05$. 
International remittances not being significant could be (perhaps) as a result of high interest rate charged by commercial banks and other formal channels through which remittances are sent to households. Interest rates charged on remittances sent internationally are estimated to be about $10 \%$. Local remittance is utilized for productive assets acquisition due to little or small interest rate charged on remittances inflow to households. From the result we reject the null hypothesis and accept the alternative.

\section{Objective 3:}

To determine if, remittances significantly alleviate financial constraint of household.
To achieve this objective, we would consider the research question: "Do remittances significantly alleviate household financial constraint?"

Remit $_{\text {it }}=x_{2} \beta_{2 \mathrm{it}}+\mu_{2 \mathrm{it}}$

$\mathbf{H}_{\mathbf{0}}$ : Remittances do not significantly alleviate household financial constraints.

$\mathbf{H}_{\mathbf{1}}$ : Remittances significantly alleviate household financial constraints.

In order to test this hypothesis, we used equation 3 $\left(\right.$ Remit $\left._{\text {it }}=x_{2} \beta_{2 \mathrm{it}}+\mu_{2 \mathrm{it}}\right)$

$x_{2} \beta_{2 \mathrm{i}}$ represents other latent variable aiding remittance. These variables are the significant variable in Appendix A and shown in Table-8.

Table-8: Remittances and household financial constraint

Marginal effects after biprobit

$\mathrm{y}=\operatorname{pr}($ remittance $)$ (predict)

\begin{tabular}{|l|l|l|l|l|ll|l|}
\multicolumn{10}{c|}{$=0.30054091$} \\
\hline Variables & dy/dx & std. Err & Z & P $>[\mathrm{z}]$ & {$[95 \%$ C. I.] } & X \\
\hline Intoth $\sim \mathrm{p}$ & 0.0740474 & 0.01028 & 7.20 & 0.000 & .53904 & .094191 & 11.5684 \\
\hline hhloca $\sim \mathrm{n}^{*}$ & -.0338292 & .02333 & -1.45 & 0.147 & -.079552 & .011893 & .509757 \\
\hline hhcomp $\sim \mathrm{r}^{*}$ & .0152493 & .03248 & 0.47 & 0.639 & -.048505 & .078904 & .164683 \\
\hline educat $\sim \mathrm{s}$ & -.0354957 & .01621 & -2.19 & 0.029 & -.06726 & -.003732 & 1.7763 \\
\hline hhfule $\sim \mathrm{y}^{*}$ & -.1245503 & .03149 & -3.96 & 0.000 & -.186263 & -.062837 & .836744 \\
\hline hhead $\sim \mathrm{s}^{*}$ & .4575978 & .02099 & 21.80 & 0.000 & .416452 & .498744 & .356497 \\
\hline
\end{tabular}

(*)dy/dx is for discrete change of dummy variable 0 to 1

Source: researcher's computation; stata 14

The result from Table- 8 , show that all other variables held constant, lntothexp is positive and statistically significant on remittance received by households. From the result, it also shows that households with an increased total household expenditure have a probability of receiving remittance by 0.074074 compared to non-remittance receiving households. Intothexp is positive and statistically significant due to $\mathrm{p}$-value $<0.05$. From the result we reject the null hypothesis. Household location is not significant could be as a result of households location being urban and the remittances received international are small since the inflow of remittances are expected to be vertical, hence urban dwellers are expected to receive remittances abroad.

\section{DISCUSSION OF RESULT}

This study analyzed the impact of remittances on productive assets acquisition from a household survey in 2009. The result shows those households that receive remittances within the last one year are more likely to utilize the remittances received for consumptive purpose and payment of utilities such as food, health care, electricity bills etc. which is in line with the view that remittances cause household members to reduce their labour supply and spend remittance income on consumption substituting for labour income. Studies that support this perception include Adams \& Cuecuecha [49], Chami et al., [50], and Durand et al., [51] contrary to the view that remittances are transitory and as such channeled into productive investment that spurs economic growth and development [47, 52, 53]. Usefulness of remittances is assumed to be mainly for consumption purpose. The null hypothesis is not rejected while the alternative hypothesis is rejected.

The result also depict that local remittances significantly impact more on acquiring productive assets by households while international remittances are not significant and are channeled towards consumption goods.

Remittances from the result obtained, increased household expenditure, thus alleviates financial constraint of household thereby smoothing their expenditure pattern. The research showed that remittances reduces households members' labour supply making them to spend remittance income on consumption substituting for labour income as opined by Chami et al., [50] and Adams and Cuecuecha [49].

\section{APPENDIX A \\ VARIABLES SPECIFICATION}

1. assets: if household acquire productive assets within the last one year (1), otherwise (0).

2. Remittances: total amount sent by migrant

3. hhsize: total household size

4. Intothexp: total household expenditure

5. hheadage: age at last birthday

6. hhhmaritalstatu: 1 if married, 0 otherwise.

7. hhfulemploy: 1 if full employed, 0 otherwise. 
8.educationstatus:(1)primary,(2)secondary,(3)tertiary

9 hhcomputer: 1yes, 0 otherwise.

10. hhcar:1yes, 0 otherwise.

11. hhfridge: 1 yes, 0 otherwise.

12. hhlocation: 1 urban, 0 otherwise.
13. hheadsex:total household size

14. int_remit: international remittances received

15. loc_remit: local remittances received

\section{APPENDIX B}

\section{Table-1}

\begin{tabular}{|c|c|c|c|c|c|c|c|}
\hline \multicolumn{3}{|c|}{$\begin{array}{l}\text { Bivariate probit regression } \\
\text { Log likelihood }=-1925.7118\end{array}$} & \multicolumn{2}{|c|}{$\begin{array}{l}\text { Number of obs } \\
\text { Wald chi2 (22) }\end{array}$} & $\begin{array}{l}= \\
= \\
=\end{array}$ & \multicolumn{2}{|c|}{$\begin{array}{r}2,087 \\
692.46\end{array}$} \\
\hline & Coef. & Std. Err. & $\mathrm{z}$ & $P>|z|$ & {$[95 \%$} & Conf. & Interval] \\
\hline \multicolumn{8}{|l|}{ asset } \\
\hline Intothhexp & .3478303 & .0360415 & 9.65 & 0.000 & .2771 & 1902 & .4184705 \\
\hline hheadsex & -.0478344 & .09978 & -0.48 & 0.632 & -.2433 & 3997 & .1477308 \\
\hline hhlocation & -.3664155 & .0723618 & -5.06 & 0.000 & -.508 & 8242 & -.2245891 \\
\hline hhfridge & -.1915999 & .0827127 & -2.32 & 0.021 & -.3537 & 7138 & -.029486 \\
\hline hhcar & -.2144386 & .0961139 & -2.23 & 0.026 & -.4028 & 8183 & -.0260589 \\
\hline hhcomputer & -.1990347 & .1099177 & -1.81 & 0.070 & -.4144 & 4693 & .0164 \\
\hline educationstatus & -.2040495 & .0540422 & -3.78 & 0.000 & -.3099 & 9704 & -.0981287 \\
\hline hhfulemploy & -.195459 & .09438 & -2.07 & 0.038 & -.3804 & 4403 & -.0104776 \\
\hline hhheadmaritalstatus & .1344115 & .0724114 & 1.86 & 0.063 & -.0075 & 5123 & .2763353 \\
\hline hhheadage & -.0110496 & .0027959 & -3.95 & 0.000 & -.0165 & 5295 & -.0055697 \\
\hline hhsize & .0144312 & .0110255 & 1.31 & 0.191 & -.0071 & 1784 & .0360407 \\
\hline _cons & -3.636233 & .4009042 & -9.07 & 0.000 & -4.421 & 1991 & -2.850475 \\
\hline \multicolumn{8}{|l|}{ remittance } \\
\hline Intothhexp & .1795725 & .0337313 & 5.32 & 0.000 & .1134 & 4603 & .2456846 \\
\hline hheadsex & -.2436686 & .0931718 & -2.62 & 0.009 & -.426 & 6282 & -.0610553 \\
\hline hhlocation & -.0325293 & .0699192 & -0.47 & 0.642 & -.1695 & 5684 & .1045098 \\
\hline hhfridge & .0689233 & .0803784 & 0.86 & 0.391 & -.0886 & 6155 & .226462 \\
\hline hhcar & .1783106 & .088474 & 2.02 & 0.044 & .0049 & 9048 & .3517164 \\
\hline hhcomputer & -.0708611 & .0987105 & -0.72 & 0.473 & -.2643 & 3301 & .1226079 \\
\hline educationstatus & -.0706443 & .0511191 & -1.38 & 0.167 & -.1708 & 8359 & .0295473 \\
\hline hhfulemploy & -.1220232 & .0902955 & -1.35 & 0.177 & -.2989 & 9991 & .0549527 \\
\hline hhheadmaritalstatus & 1.222708 & .0660244 & 18.52 & 0.000 & 1.093 & 3303 & 1.352114 \\
\hline hhheadage & .0182558 & .002676 & 6.82 & 0.000 & .013 & 3011 & .0235006 \\
\hline hhsize & -.0284997 & .0111149 & -2.56 & 0.010 & -.0502 & 2846 & -.0067148 \\
\hline _cons & -3.403758 & .3923296 & -8.68 & 0.000 & -4.17 & 7271 & -2.634806 \\
\hline /athrho & .1046699 & .0479513 & 2.18 & 0.029 & .0106 & 6872 & .1986527 \\
\hline rho & .1042894 & .0474297 & & & .0106 & 6868 & .1960801 \\
\hline
\end{tabular}

Likelihood-ratio test of rho=0: $\quad \operatorname{chi2}(1)=4.78493 \quad$ Prob $>\operatorname{chi} 2=0.0287$

Source: Researcher's computation; stata 14

\begin{tabular}{|c|c|c|c|c|c|c|c|}
\hline $\begin{array}{c}\text { Marginal } \\
y=\end{array}$ & $\begin{array}{l}\text { fects after } \\
\operatorname{Pr} \text { (asset) } \\
.17166872\end{array}$ & dict) & & & & & \\
\hline variable & $\mathrm{dy} / \mathrm{dx}$ & Std. Err. & z & $\mathrm{P}>|\mathrm{z}|$ & $95 \%$ & C.I. ] & $\mathrm{X}$ \\
\hline int revt* & -.022517 & .02491 & -0.90 & 0.366 & -.071344 & .02631 & .149453 \\
\hline loc_rent* & .0591433 & .02593 & 2.28 & 0.023 & .008318 & .109968 & .18515 \\
\hline lntoth $\sim p$ & .070496 & .00796 & 8.85 & 0.000 & .054885 & .086107 & 11.5684 \\
\hline hhloca $\sim n^{\star}$ & -.0913718 & .01788 & -5.11 & 0.000 & -.126424 & -.05632 & .509757 \\
\hline hhcomp ${ }^{\sim} r^{\star}$ & -.0703229 & .02123 & -3.31 & 0.001 & -.111941 & -.028705 & .164683 \\
\hline educat $\sim S$ & -.0483147 & .01269 & -3.81 & 0.000 & -.073184 & -.023445 & 1.7763 \\
\hline hhfule ${ }^{\sim} y^{\star}$ & -.0132302 & .0232 & -0.57 & 0.568 & -.058697 & .032236 & .836744 \\
\hline hhhead $\sim S^{\star}$ & .0061997 & .01987 & 0.31 & 0.755 & -.032739 & .045138 & .356497 \\
\hline
\end{tabular}

$\left.{ }^{*}\right) \mathrm{dy} / \mathrm{dx}$ is for discrete change of dumm variable from 0 to 1

Source: Researcher's computation; stata 14 
Table-2

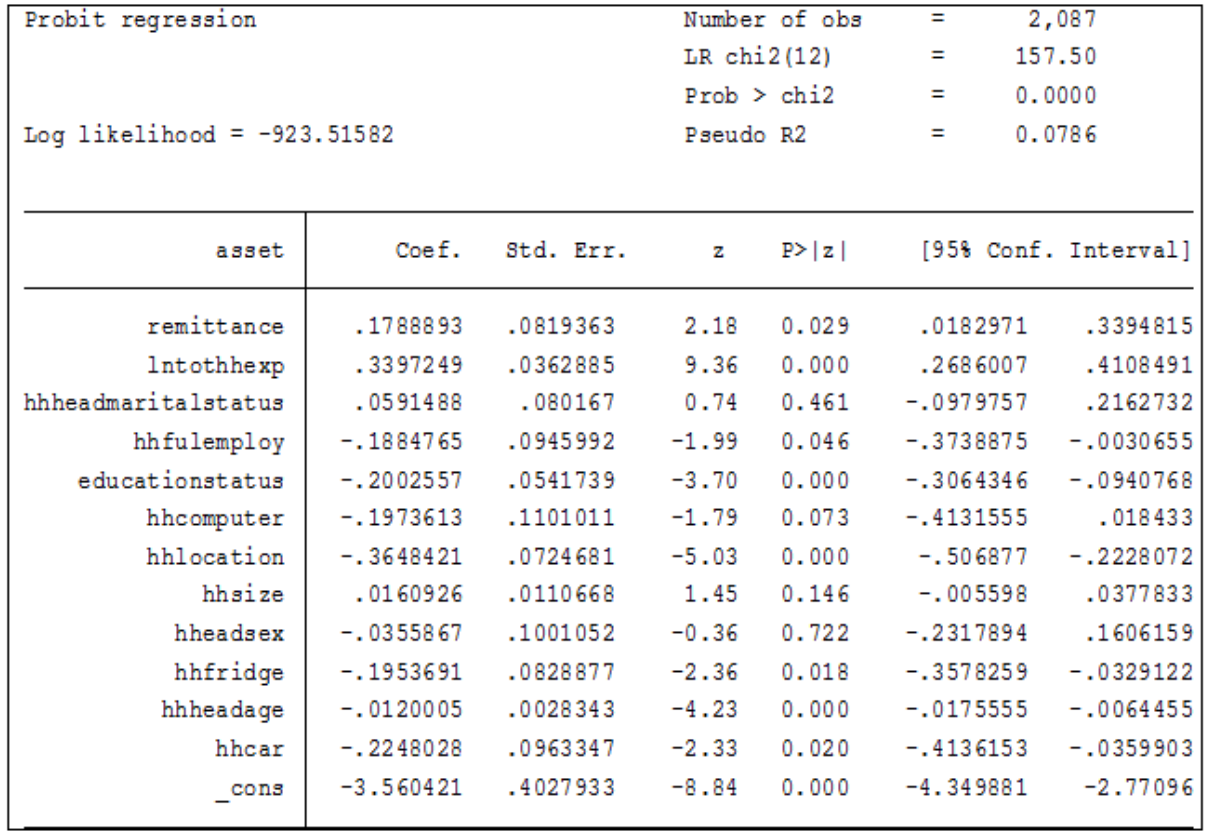

Source: Researcher's computation; stata 14

Table-3

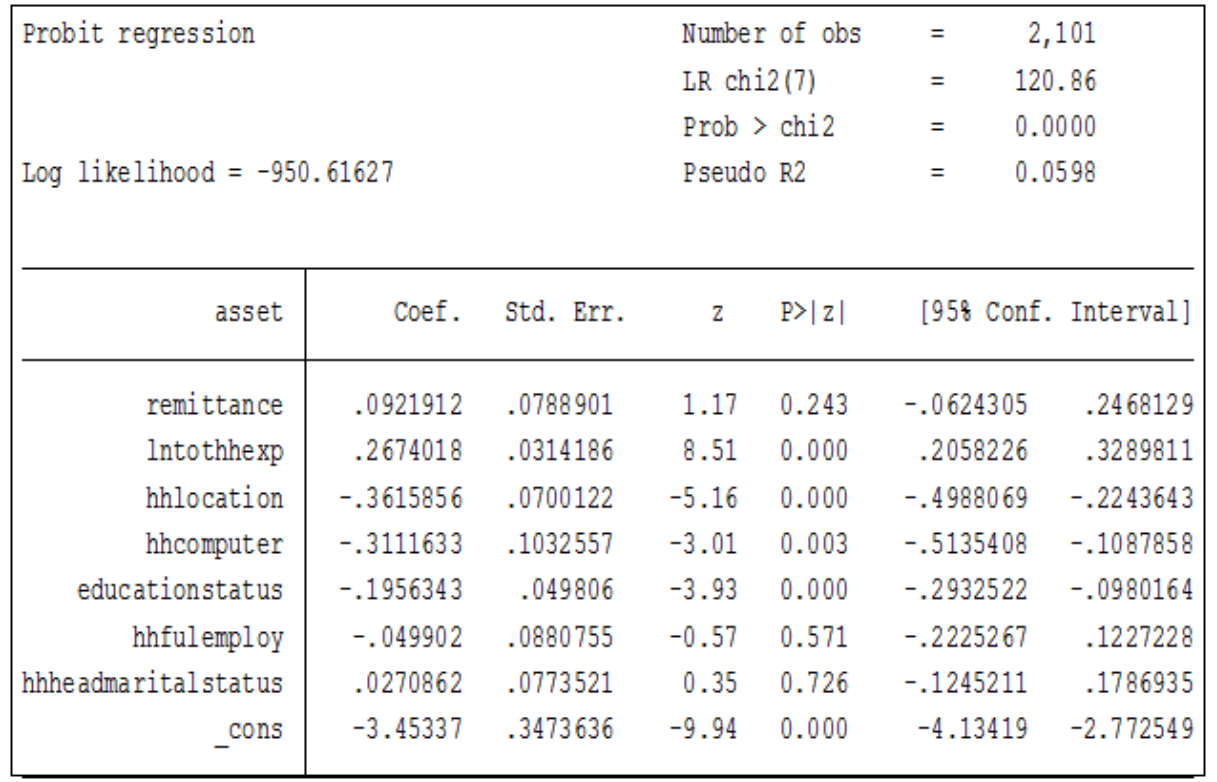

Source: Researcher's computation; stata 14

Table-4

\begin{tabular}{|c|c|c|c|c|c|c|c|}
\hline \multicolumn{8}{|c|}{$\begin{array}{l}\text { Marginal effects after probit } \\
\begin{aligned} \mathrm{y} & =\operatorname{Pr}(\text { asset) (predict) } \\
& =.17251402\end{aligned}\end{array}$} \\
\hline variable & $d y / d x$ & std. Err. & $z$ & $\mathrm{P}>|z|$ & $95 \%$ & C.I. & $\mathrm{x}$ \\
\hline remitt $\sim e^{\star}$ & .0238869 & .02073 & 1.15 & 0.249 & -.016739 & .064513 & .334603 \\
\hline hhhead s* & .0069443 & .0199 & 0.35 & 0.727 & -.032063 & .045951 & .356497 \\
\hline hhfule $\sim y^{\star}$ & -.0129488 & .02321 & -0.56 & 0.577 & -.058437 & .032539 & .836744 \\
\hline educat $\sim s$ & -.0499728 & .01269 & -3.94 & 0.000 & -.074838 & -.025108 & 1.7763 \\
\hline hhcomp $\sim r^{*}$ & -.0716628 & .02118 & -3.38 & 0.001 & -.113177 & -.030148 & .164683 \\
\hline hhloca n* & -.0926117 & .01789 & -5.18 & 0.000 & -.127684 & -.05754 & .509757 \\
\hline lntoth p & .0683051 & .00793 & 8.61 & 0.000 & .05276 & .083851 & 11.5684 \\
\hline
\end{tabular}


Table-5

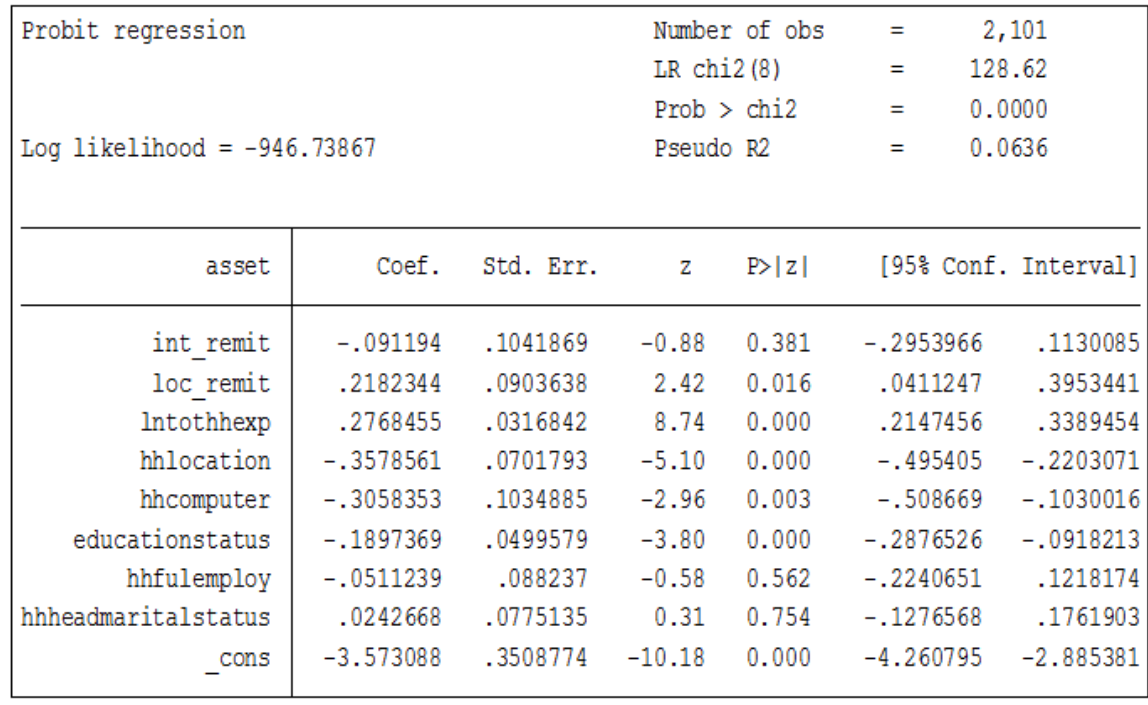

Source: Researcher's computation; stata 14

Table-6

\begin{tabular}{|c|c|c|c|c|c|c|c|}
\hline \multicolumn{8}{|c|}{$\begin{array}{l}\text { Marginal effects after probit } \\
\qquad \begin{aligned} y & =\operatorname{Pr} \text { (asset) (predict) } \\
& =.17166872\end{aligned}\end{array}$} \\
\hline variable & $\mathrm{dy} / \mathrm{dx}$ & Std. Err. & $z$ & $\mathrm{P}>|\mathrm{z}|$ & $95 \%$ & C.I. ] & $X$ \\
\hline int_re $e^{\sim *}$ & -.022517 & .02491 & -0.90 & 0.366 & -.071344 & .02631 & .149453 \\
\hline loc_rent* & .0591433 & .02593 & 2.28 & 0.023 & .008318 & .109968 & .18515 \\
\hline lntoth $\sim p$ & .070496 & .00796 & 8.85 & 0.000 & .054885 & .086107 & 11.5684 \\
\hline hhloca $n^{\star}$ & -.0913718 & .01788 & -5.11 & 0.000 & -.126424 & -.05632 & .509757 \\
\hline hhcomp $\sim r^{\star}$ & -.0703229 & .02123 & -3.31 & 0.001 & -.111941 & -.028705 & .164683 \\
\hline educat s & -.0483147 & .01269 & -3.81 & 0.000 & -.073184 & -.023445 & 1.7763 \\
\hline hhfule $y^{\star}$ & -.0132302 & .0232 & -0.57 & 0.568 & -.058697 & .032236 & .836744 \\
\hline hhhead $S^{\star}$ & .0061997 & .01987 & 0.31 & 0.755 & -.032739 & .045138 & .356497 \\
\hline
\end{tabular}

Source: Researcher's computation; stata 14

Table-7

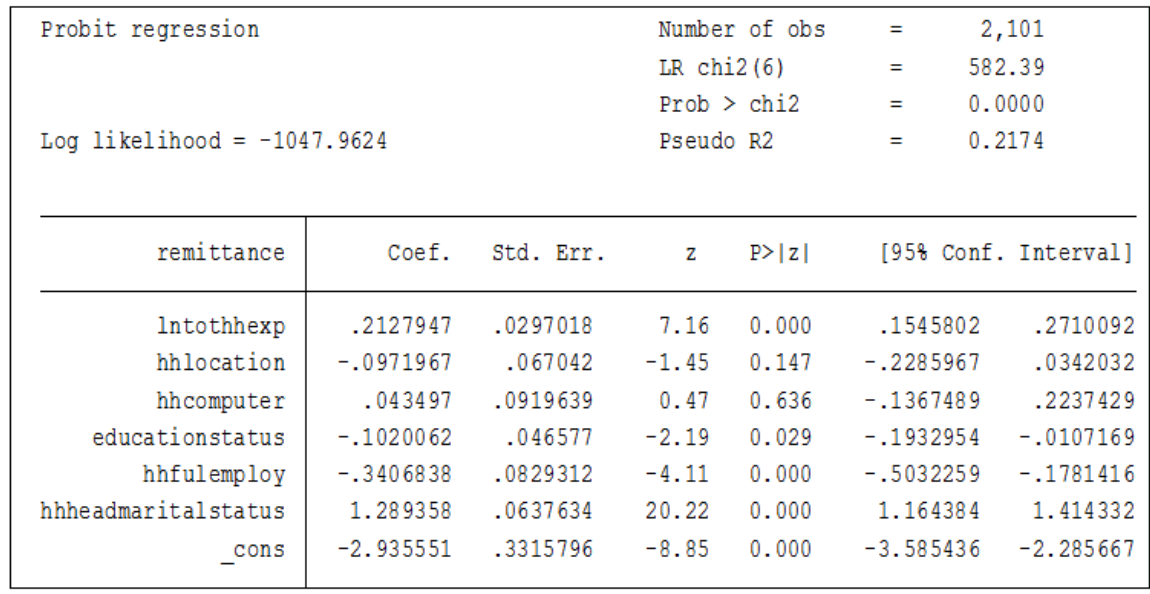

Source: Researcher's computation; stata 14 
Table-8

\begin{tabular}{|c|c|c|c|c|c|c|}
\hline \multicolumn{7}{|c|}{$\begin{array}{l}\text { Marginal effects after probit } \\
\qquad \begin{aligned} y & =\operatorname{Pr}(\text { remittance) (predict) } \\
& =.30054091\end{aligned}\end{array}$} \\
\hline variable & $\mathrm{dy} / \mathrm{dx}$ & Std. Err. & $z$ & $\mathrm{P}>|z|$ & 958 C.I. & $\mathrm{X}$ \\
\hline lntoth p & .0740474 & .01028 & 7.20 & 0.000 & $.053904 \quad .094191$ & 11.5684 \\
\hline hhloca n * & -.0338292 & .02333 & -1.45 & 0.147 & $-.079552 \quad .011893$ & .509757 \\
\hline hhcomp $\sim \mathrm{r}^{*}$ & .0152493 & .03248 & 0.47 & 0.639 & $-.048405 \quad .078904$ & .164683 \\
\hline educat $\sim S$ & -.0354957 & .01621 & -2.19 & 0.029 & $-.06726-.003732$ & 1.7763 \\
\hline hhfule $\sim y^{*}$ & -.1245503 & .03149 & -3.96 & 0.000 & $-.186263-.062837$ & .836744 \\
\hline hhhead $\sim S^{*}$ & .4575978 & .02099 & 21.80 & 0.000 & $.416452 \quad .498744$ & .356497 \\
\hline
\end{tabular}

$\left.{ }^{*}{ }^{*}\right) \mathrm{dy} / \mathrm{dx}$ is for discrete change of dumny variable from 0 to 1

Source: Researcher's computation; stata 14

\section{CONCLUSION}

The main objective of this study is to examine the impact of remittances on productive assets acquisition and a micro cross-sectional data was used in the estimation of the model. Specifically, the study is aimed at examining whether remittances impact significantly on productive assets acquisition, examining the type of remittances that contributes to the acquisition of productive assets and to determine if remittances significantly alleviate financial constraint of households in Nigeria. We concluded that there is a positive and insignificant effect of migrant remittances on propensity to acquire productive assets among Nigeria's households. Thus, remittances alleviate financial constraint. The model estimated was based on bivariate probit regression equation which saw remittances and productive assets as endogenous variables determined by some observed variables.

Diaspora incomes are fluid and require a targeted system by a well-meaning strategy to harness. Government must not allow remittances to diffuse in the economy or else its intended result will be hindered. Idea through Non-Governmental Organizations (NGOs) or a ministry to mobilize and galvanize the various groups in different countries to educate them on the usefulness of their remittances and also how it could be put to proper use. Nigerian government cannot sit back home at the destination to guide how the remittances could be used but can enhance usefulness by synergies at the country of origin. By so doing recipients of remittances could be guided on how best to allocate their income to productive purchases.

\section{REFERENCES}

1. World Bank Indicator. (2011). Migration and remittances: Recent developments and outlook (Migration and Development Brief 26). Washington, DC: World Bank.

2. World Bank. (2016). Migration and remittances: Recent developments and outlook (Migration and Development Brief 26). Washington, DC: World Bank.

3. Sharaf, M. F. (2014). The remittances-output nexus: Empirical evidence from Egypt, Economics Research International (online). Available at: http://dx.doi.org/10. 1155/2014/965240Accessed 2nd sept, 2018.

4. Simiyu, C. N. (2013). Remittance and Household Expenditures in Kenya. Journal of Emerging Issues in Economics, Finance and Banking (JEIEFB), 2(3).

5. Urama, N. E., Nwosu, E. O., \& Yuni, D. N. (2016). International Migrant Remittances and Labour Supply in Nigeria. John Wiley \& Sons Ltd, No. 12289.

6. Udah, E. B. (2011). Remittances, human capital and economic performance in Nigeria. Journal of sustainable development in Africa, 13(4).

7. Ajefu, B. J. (2018). Impact of remittances on physical assets accumulation among Nigerian households. Migration and development journal. 7. https//doi.org.1080/21632324.2017.

8. Adams Jr, R. H., \& Cuecuecha, A. (2013). The impact of remittances on investment and poverty in Ghana. World Development, 50, 24-40.

9. Agwu G. A., Yuni, D. N., \& Anochiwa, L. (2017). Do remittances improve income inequality? International organization for migration. 
10. Abbas K., Sabir, H. M., Shehzadi, A., \& Abbas, Q. (2014). Impact of workers' remittances on household welfare in District Jhang. Journal of Finance and Economics, 2(4), 131-135.

11. Jean, C. F., Lauren, B., Linda, V., \& Zachariah, J. (2015). Strengthening the home-to-facility continuum of newborn and child health care through m Health: Evidence from an intervention in rural Malawi. African Population Studies Special Edition, 2015; 1663. http://aps.journals.ac.za

12. Ratha, D. (2003). Workers' remittances: An important and stable source of external development finance, Global development and finance. Striving for stability in Development Finance, 157-175. World Bank, Washington DC.

13. Bang, J. T., Mitra, A., \& Wunnava, P. V. (2016). Do remittances improve income inequality? an instrumental variable quantile analysis of the Kenyan case? Economic Modelling, 58: 394-402. https://doi.org/doi:

10.1016/j.econmod.2016.04.004.

14. Catrinescu, N., Leon-Ledesma, M., Piracha, M., \& Quillin, B. (2009). Remittances, institutions, and economic growth, World Development, 37(1): 8192. org/10.1016/j.worlddev.2008.02.004.

15. Feeny, S., S. Iamsiraroj, and M. Mcgillivray (2014), "Remittances and economic growth: Larger impacts in smaller countries?", The Journal of Development Studies, 50(8): 1055-1066. https://doi.org/10.1080/00220388.2014.895815.

Focus Migration

16. Giuliano, P., \& Ruiz-Arranz, M. (2005). Remittances, Financial Development, and Growth IMF Working Paper. No. 234, Washington: International Monetary Fund.

17. Mundaca, G. (2009). Remittances, Financial market development, and economic growth: The case of Latin America and the Caribbean, Review of Development Economics, 13(2):288-303.

18. Aggarwal, R., Demirg€uc-Kunt, A., \& Peria, M. S. M. (2011). Do remittances promote financial development?" Journal of Development Economics, 96(2): 255-264.

19. Chowdhury, M. (2016). Financial development, remittances and economic growth: Evidence using a dynamic panel estimation" Margin: The Journal of Applied Economic Research, 10(1),35-54.

20. Aliyu, S. U. R., \& Englama, A. (2009). Is Nigeria ready for inflation targeting?.

21. Adenutsi, D. E. (2010). Do international remittances promote human development in poor countries? Empirical evidence from Sub-Saharan Africa.

22. Hein De Haas. (2007). Remittances, Migration and Social Development. Social Policy and Development Programme Paper Number 34. United Nations Research Institute for Social Development.
23. Taylor, J. B. (1999). A historical analysis of monetary policy rules. In Monetary policy rules (pp. 319-348). University of Chicago Press.

24. Anyanwu, J. C., \& Erhijakpor, A. E. (2010). Do international remittances affect poverty in Africa?. African Development Review, 22(1), 5191.

25. Massey, D., \& Denton, N. A. (1993). American apartheid: Segregation and the making of the underclass. Harvard university press.

26. Massey, D. S., Arango, J., Hugo, G., Kouaouci, A., Pellegrino, A., \& Taylor, J. E. (1994). An evaluation of international migration theory: The North American case. Population and development Review, 699-751.

27. Acosta, P. (2006). Labor supply, school attendance, and remittances from international migration: the case of El Salvador. The World Bank.

28. Beine, M., Docquier, F., \& Rapoport, H. (2001). Brain drain and economic growth: theory and evidence. Journal of development economics, 64(1), 275-289.

29. Beine, M., Bos, C. S., \& Coulombe, S. (2012). Does the Canadian economy suffer from Dutch disease?. Resource and Energy Economics, 34(4), 468-492.

30. Commander, S., Svejnar, J., \& Tinn, K. (2008). Explaining the performance of firms and countries: What does the business environment play?.

31. Gibson, J., \& McKenzie, D. (2012). The economic consequences of 'brain drain'of the best and brightest: Microeconomic evidence from five countries. The Economic Journal, 122(560), 339375 .

32. Ozden, C., \& Schiff, M. (2006). International migration, remittances, and the brain drain Washington. DC: World Bank.

33. Stark, O., \& Byra, L. (2012). A Back-Door Brain Drain. ZEF-Discussion Papers on Development Policy, 164. Zentrum für Entwicklungsforschung.

34. Barajas, A., Chami, R., Fullenkamp, C., Gapen, M., \& Montiel, P. J. (2009). Do workers' remittances promote economic growth?. IMF Working Papers, 1-22.

35. Chami, R., Barajas, A., Cosimano, T., Fullenkamp, C., Gapen, M., \& Montiel, P. (2008). Macroeconomic consequences of remittances (p. 259). Washington, DC: International Monetary Fund.

36. Imai, S. I., \& Guarente, L. (2014). NAD+ and sirtuins in aging and disease. Trends in cell biology, 24(8), 464-471.

37. Guha, R., \& Alier, J. M. (2013). Varieties of environmentalism: essays North and South. Routledge.

38. Chigurupati, S., Mughal, M. R., Okun, E., Das, S., Kumar, A., McCaffery, M., ... \& Mattson, M. P. (2013). Effects of cerium oxide nanoparticles on 
the growth of keratinocytes, fibroblasts and vascular endothelial cells in cutaneous wound healing. Biomaterials, 34(9), 2194-2201.

39. Acosta, P. A., Lartey, E. K., \& Mandelman, F. S. (2007). Remittances and the Dutch Disease, Federal Reserve Bank of Atlanta. Working Paper 8.

40. LeMaelan, G. (2010). How remittances contributes poverty reduction, centred'tudes et de recherché sur le developpement international, CERDI-CNRS university of Auvergne (france).

41. Iheke, O. R. (2012). The effect of remittances on the Nigeria Economy, International journal of development and sustainability, 1(2).

42. Amel, S. O., Stephen, B., Dario, L., Zane, K., Marsha, B., \& Amy, H. (2014). The effects of household assets inequality and conflict on population health in Sudan. African Population Studies, 28(3), 2014. http://aps.journals.ac.za

43. Yameogo, N. D. (2014). Analysis of Household Expenditure and the Impact of Remittances using Latent Class Model: the Case of Burkina Faso. Working Paper Series No. 200, African Development Bank Tunis, Tunisia.

44. Quartey, P. (2006). The impact of Migrant Remittance on household welfare in Ghana. African Economic Consortium, Nairobi (AERC) research paper, 158.

45. Simon, D., Joshy, E., \& Atanu, G. (2007). Mental Accounting and Remittances: A study of Malawian Rural Households. URL:http://www.simon- davies.org.uk/RemitMenAcc
46. Soraya, J. S. (2007). Overseas Workers, Remittances and Household Welfare in the Philippines. 6 PEP General Meeting at Sheraton Lima Hotel, Paseo de la Republic 170, Lima, Peru, June 14-16, 2007.

47. Jena, F. (2017). Migrant remittances and physical investment purchase: Evidence from Kenyan households. The journal of development studies.

48. Denis, N. Y., Nathaniel, E. U., \& Christian, O. U. (2018). Migrant Remittances and Household Expenditure Patterns: Case Study of Enugu and Anambra States of Nigeria. World Applied Sciences Journal, 36(2):319-327.

49. Adams, R. H., \& Cuecuecha, A. (2010). Remittances, household expenditure and investment in Guatemala. World Development, 38(11), 1626-164.

50. Chami, R., Fullenkamp, C., \& Jahjah, S. (2005). Are immigrant remittance flows a source of capital for development? IMF Staff Papers, 52(1):55.

51. Durand, G. M., \& Konnerth, A. (1996). Long-term potentiation as a mechanism of functional synapse induction in the developing hippocampus. Journal of Physiology-Paris, 90(5-6), 313-315.

52. Osili, U. O. (2004). Migrants and housing investments: Theory and evidence from Nigeria. Economic Development and Cultural Change, 52(4), 821-849.

53. Woodruff, C., \& Zenteno, R. (2007). Migration networks and microenterprises in Mexico. Journal of Development Economics, 82(2), 509-528. 